Mavi Atlas, 5(1)/2017: 238-268.

Araştırma Makalesi | Research Article

Makale Geliş | Received: 16.03.2017

Makale Kabul | Accepted: 19.04.2017

Doi: 10.18795/gumusmaviatlas.309747

\title{
Funda SONGUR
}

Öğretim Görevlisi | Lecturer Pîrî Reis Üniversitesi, Denizcilik Meslek Yüksek Okulu, İstanbul-Türkiye Pîrî Reis University, Maritime Brokerage Programme, İstanbul-Turkey

fsongur@pirireis.edu.tr

\section{Geçmişten Günümüze Aydıntepe: Tarih, Kültür ve Ekonomi}

\section{Öz}

$\mathrm{Bu}$ çalışmada, Bayburt'un ilçelerinden biri olan Aydıntepe, bölgenin sahip olduğu kültür, medeniyet ve ekonomi yapıları çerçevesinde incelenmiştir. Aydıntepe, diğer adı ile Hart, Bayburt'un kültür ve ekonomi yapısından ayrı düşünülemeyeceği için bulunduğu bölge ile birlikte değerlendirilmiştir. Çalışmada, Bayburt hakkında yazılmış telif eserlerin dikkate alınmasının yanı sıra bölge yerleşimleri ziyaret edilmiş ve ziyaretler esnasında ortaya çıkan gözlemler, yapılan görüşmeler ve elde edilen sonuçlar bu çalışmaya yansıtılmıştır. Coğrafi konum itibariyle Doğu Karadeniz içerisinde yer alan Aydıntepe, Eski Tunç Çağı'ndan bu yana birçok kültüre ev sahipliği yapmış, Selçuklular öncülüğünde Türklerin Anadolu'da yerleştiği ilk bölgelerden biri olmuş ve yüzyıllardır Türkler tarafından yönetile gelmiş bir bölgedir. Bu yazının ana teması, ilçenin tarihi ve tarihi yapıları, bugün ziyaret edilebilecek yerleri, günümüze kadar yaşamış sosyal ve kültürel öğeleri ile birlikte bölgenin geçmişten bugüne bütünsel iktisadi değerlendirmesidir. İlçenin iktisadi yapısı değerlendirilirken nüfus verileri dikkate alınmış ve bu nüfusun bölgede hâlihazırda kurulu iktisadi yapıdaki gücüne yer verilmiştir.

Anahtar Kelimeler: Aydintepe, Hart, Bayburt.

\section{Past and Present of Aydintepe: History, Culture and Economy}

\begin{abstract}
Aydıntepe, one of the districts of Bayburt, is studied within the scope of culture, civilisation and economy as part of culture and economy of Bayburt due to the fact that Aydintepe, in other name Hart, cannot be separated from its own territorial progress. Besides researches conducted on Bayburt as a mean of sources for this study, personal visits ended up with various observations and interviews are also taken into account. Hart, geographically located in the Eastern Black Sea Region has been welcomed many culture since Bronze Age, it was one of first settlement areas in Anatolia for Seljuks and has been ruled by Turks for many centuries. Hart's history and historical structures, social and cultural factors that are existed up until today and economical history are main concerns of this study. Economical aspects are investigated by population data reveals its importance within today's regional economy and its foundations.
\end{abstract}

Keywords: Aydıntepe, Hart, Bayburt. 


\section{Bölgenin Coğrafi Konumu}

Aydıntepe'nin bağlı olduğu Bayburt ili, coğrafi konum itibariyle Kop ve Soğanlı Dağları arasında kalan ve Çoruh Nehri'nin açtığı düz bir vadide kurulu Doğu Karadeniz Bölgesi sınırları içindedir. 1.550 metre rakımlı şehrin yüzölçümü $3.652 \mathrm{~km}^{2}$ 'dir. Doğu Karadeniz'de Yukarı Çoruh Havzası'nda yer alan Bayburt Ovası, Keçevidüzü, Mormuş Düzlüğü, Düzüker Ovası ve Hart Ovası olmak üzere dört ana bölümden oluşur. Bu düzlüklerin dışında şehrin neredeyse yarısı tepelik ve dağlıktır.

Aydıntepe, eski adı ile Hart, Bayburt ilinin iki ilçesinden biri olup sınırları itibariyle Trabzon ve Gümüşhane illerine komşudur. Aydıntepe Ovası ile Soğanlı sıradağlarından oluşan bölge 1.450-1.550 metre yükseklik ile orman örtüsünden yoksun geniş otlaklara sahip olduğundan Bayburt ilinin tarım ve hayvancılıkta en verimli alanlarından biridir. Bayburt sınırları içerisinde toplam alanı $473 \mathrm{~km}^{2}$ olan Aydıntepe, il merkezine karayolu ile 24 km uzaklıktadır.

Genel anlamda Bayburt karasal iklimin etkisi altındadır. Denize yakın olmasına rağmen çevrelendiği dağlar sebebi ile iklimi ve bitki örtüsü Doğu Anadolu iklim tipine daha yakındır. Bölgede yazlar kurak geçerken kışlar ise soğuk ve kar yağışlıdır. Aydıntepe'de sıcaklık Bayburt'tan daha düşük değerlerdedir. En sıcak aylar Temmuz ve Ağustos ayları iken kış ayları oldukça soğuk geçer ve bu durum bölgenin yıllık ortalama sıcaklıklarını düşürür. Bölgenin iklim ve toprak yapısının özellikleri, akarsu ve derelerin varlığı ile yoğunluğu, bölgenin yüzey şekilleri gibi coğrafik özellikler bu araştırmanın konusu olan bölgenin tarihi, medeniyeti ve ekonomisi için önem arz etmektedir.

\section{Bölgenin Tarihi}

\subsection{Kent Adının Kökeni}

Şehrin adı Ortaçağ Ermeni kaynaklarında Payberd; Bizans kaynaklarında Payper, Baberd ve Paypert olarak geçmektedir. 13. yüzyıl sonlarında bu bölgeden geçen Marco Polo'nun seyahatnâmesinde Paipurth ve Baiburt olarak anılır. Arap kaynaklarında Babirt; II. Mesud adına 1291'de basılan bir parada Baypırt; Akkoyunlu 
tarihinden bahseden çağdaş eserlerde Papirt şeklinde geçer. Bu kelimenin son hecesi "berd"in "yüksek kale" anlamına geldiği bilinmekteyse de ilk hecesinde bir anlam bulunamamıştır. Osmanlı dönemine ait kaynaklarda ise şehrin ismi bugünkü söylenişine uygun olarak Bayburd şeklinde geçmektedir (Miroğlu 1992: 226).

\subsection{Türk Hâkimiyeti Öncesinde Bölge Tarihi}

Bayburt ve çevresinde yerleşim tarihi M.Ö. 4000 sonlarına tarihlendirilmiş olsa da bölgede Paleolitik dönemlerden itibaren yaşam izlerinin varlığı söz konusudur. $\mathrm{Bu}$ sebeple Bayburt ve çevresinde tarih öncesi dönemlere ait buluntular ve yerleşim yerlerine rastlanabilmektedir. Geç Kalkolitik ve İlk Tunç Çağı'nda Bayburt, Erzurum ve çevresi diğer prehistorik döneme nazaran görece önemlidir. Karaz (Hurri) kültürüne ait ilk buluntular bu devirlere tarihlendirilmiştir (Ünsal 2006: 36-52). Diğer bir ifade ile Bayburt yöresi, M.Ö. 4000 sonu itibariyle coğrafi manada Karaz; etnik manada ise Hurri kültürü içerisine dâhil olmuştur. M.Ö. 14. yüzyıldan itibaren farklı krallıkların adı geçse de bölgede uzun süreli bir hâkimiyet görülmemiştir. Bu süreçte bölge, Hayaşa ve Azzi Krallıkları ile Diauhei Beyliği ve Urartuların egemenliği altında kalmıştır (Özger 2008: 27; Pehlivan 1994: 333). Urartulara ait yap1 özellikleri bağlamında mevcut kalenin sağlamlaştırılma tarzı benzer yapıda olduğundan bölgede Urartu hâkimiyetinin varlığı düşünülüyor olmasına rağmen Aydıntepe ve çevresinde tamamen hâkimiyet kurmuşlardır demek zordur (Çiğdem 2013: 74). Yüzey araştırmaları esnasında keşfedilen Roma buluntuları, Roma İmparatorluğu'nun bölgede söz sahibi olduğunu ve imparatorluğun ikiye ayrılmasıyla birlikte bölgenin, Bizans topraklarına dâhil edildiği kanıtlamıştır. Böylece Bayburt, Bizans’ın önemli bir Doğu sınırı kenti olmuştur. Hatta Bizans'ın yedi piskoposluğunun dördüncüsü konumundadır (Bayburt Nüfus Defterleri 2015: 17). Bu dönemde İmparator Iustinianos Bayburt Kalesi’ni tahkim ettirmiş, şehir daha sonra Arap fetihleri sırasında Bagrat sülalesinin hâkimiyeti altına girmiştir (Miroğlu 1992: 226). 


\subsection{Bölgede Türk Hâkimiyetinin Sağlanması ve Devam Eden Süreç}

M.S. 1054 yılına kadar birkaç kez Müslüman toplulukların akınına uğrayan Bayburt, Türk yurdu olmak için Tuğrul Bey zamanını ve Malazgirt Zaferi sonrası Selçukluların buraya gelişini bekleyecekti. Zafer sonrası kısa süre Bizans egemenliğine geçse de tekrar geri alınan bölge, Türklerin Anadolu'da hâkim olduğu ilk yerleşim alanlarından biri oldu. Kazanılan zafere istinaden Sultan Alparslan Bayburt'u komutanlarından Ebu'l Kasım Saltuk'a ikta olarak vermiştir. İlk Türk Beyliklerinden Saltuklular Bayburt ile birlikte egemen olduğu Erzurum, İspir, Tortum, Pasinler, Oltu, Micingerd ve Tercan'1 Büyük Selçuklulara tabi kılmıştır. 1202 yılında Türkiye Selçuklularına dâhil edilen Bayburt bölgesi 1230 yılında Konya'ya bağlanmış (Arslan 2015: 188), 1230 y1lında ise Erzurum Beyliği’ne son verilerek tamamen Selçuklu Türkiye'si topraklarına dâhil edilmiş, Selçuklu döneminde şehir, uç sınır şehri anlamına gelen dâr üs-suğr unvanı almıştır (Özger 2008: 29-30). Moğol istilalarından kaçmak suretiyle sığınak olarak kullanılan Bayburt, ticari ağ üzerinde bulunması sebebiyle istilalar sonrası hızlı bir gelişme göstermiştir. Sırasıyla İlhanlılar, Eretnalılar, Erzincan Beyi Mutahharten, Akkoyunlular, Karakoyunlular ve yeniden Akkoyunlular ve Safeviler, Osmanlı hâkimiyetine kadar bu bölgeye hükmetmişlerdir.

Bayburt'ta Osmanlı hâkimiyeti, bölgenin 1514 yılında Yavuz Sultan Selim tarafından fethedilmesiyle ve Erzincan ile birlikte uç beylerbeyliği olarak ilan edilmesiyle başlamıştır. Bağlı olduğu beylerbeyliği sürekli değişen Bayburt'un 16. yüzyıla ait tahrir defterlerine göre on mahallesi bulunuyordu. Şehrin toplam nüfusu 1516 yılında 2.477, 1520 yilında 4.935, 1530 y1lında 3.231 ve 1591 y1lında 5.630 olarak tespit edilmiş; yıllar içerisinde nüfus yükselmeye devam etmiştir. 16. yüzyılda ortalama olarak nüfusun \% 40'ını Müslüman ve \% 60'ını ise Hıristiyan unsurlar oluşturuyordu (Miroğlu 1992: 227). Bu oranlar, Müslüman nüfusun artması ile birlikte bir sonraki yüzyılda değişiklik göstermiştir. Yavuz Selim sonrası tahta geçen Kanuni döneminde Bayburt'un önemi bir kat daha artmış ve şehrin kalesi esaslı bir onarımdan geçirilmiştir (İnbaşı 2007: 91). 
Şehir, 17. yüzyıla kadar Erzincan, Diyarbekir ve Rum Beylerbeyliklerine bağlanmış, Erzurum Beylerbeyliği kurulduktan sonra oraya bağlı bir sancak olmuş, daha sonra Erzurum eyaletinin Erzurum sancak kazası olarak idari taksimatta yerini almıştır (İnbaş1 2007: 92; Özger 2008: 116-118). 17. yüzyılda yaşanan Celali ayaklanmaları sırasında Bayburt, Kuyucu Murad Paşa'nın bulunduğu yerleşim alanlarından biri olmuştur. Hatta Trabzon Beylerbeyi tarafindan zulüm altında olan Bayburt halkını da o kurtarmıştır (Özger 2008: 35-37). Bayburt, 19. yüzyıla kadar bu konumunu korumuş, 19. yüzyılda Osmanlı modernleşmesi ile gelen idari teşkilatlanma sırasında değişikliğe uğramıştır. Zira bu yüzyılın ikinci yarısında karşı karşıya kalınan göçler ve işgaller sonrası oluşan yeni sınırlar ve yeni nüfus durumu yeni teşkilatlanmayı gerekli kılmıştır. Dönemin Erzurum Valisi İsmail Hakkı Bey, sadarete sunduğu yeni teklifinde merkezi Bayburt kazası olup Erzurum'a bağlı kalacak bir Bayburd Sancağı Mutasarrıflığı önermiştir. Teklifin detayına bakıldığında Bayburt Sancağının Gümüşhane Sancağına bağlı olup Kelkit, Şiran, İspir, Tortum ve Keskim kazalarından ve Tavusker dağ köylerinden oluşması önerilmiştir. Aynı zamanda Çıldır Heyeti'nin de Bayburt'ta oturması öneri kapsamındaydı. Bu öneri ise 1878 yılında onaylanmıştır (Özger 2008: 121). Fakat bu yeni düzenleme oldukça kısa sürmüş olup bu kapsamda ilk öneri Tortum nahiyesinin Erzurum'a bağlanması isteğiydi. Daha sonra Kelkit ve Şiran kazaları da Gümüşhane'ye bağlı kalmak üzere Bayburd Sancağı'ndan ayrılmak istedi. $\mathrm{Bu}$ istekler doğrultusunda onaylanan değişiklikler neticesinde Bayburt sadece merkez ve İspir'den ibaret bir duruma düşünce sancak statüsü de kaldırıldı. 1888 yılında Erzincan Sancağı'na bağlandı. Bayburt Sancağı'nın lağvedildiği tezkerenin Meclis-i Vükelâ Mazbatası'nda ilan edilmesinden hemen sonra ise Bayburt halkının itirazı üzerine Bayburt tekrar Erzurum'a bağlanmıştır. Yöre halkı dilekçe ile sadarete başvurmuş, bu dilekçede Bayburd Sancağı'nın lağvedilmesi yerine Gümüşhane Sancağı'nın lağvedilmesini talep etmiştir. Fakat bu istekleri makamlarca dikkate alınmamıştır. Özetlemek gerekirse 16. yüzyılda ilk kez sancak olmuş fakat kısa bir süre idari konumunu korumuş olan Bayburt, yukarıda bahsi geçen sürece kadar kaza olarak kalmıştır. Çok kısa süren bir sancak statüsü olduysa da tekrar kaza konumuna 
getirilmiştir. Hart (Aydıntepe) bölgesi de Bayburt'un yukarıdaki siyasi ve idari tarihi içerisinde Bayburt ile birlikte aynı değişikliklere tâbi olmuş bir yer olmuştur.

Bölge, özellikle Doğu’ya yapılan seferlerde zahirelerin karşılandığı bir merkez olmuştur. Türkiye Cumhuriyeti kurulana kadar iki kere Rus işgaline uğraması ayrı tutulursa bölge herhangi bir siyasi gelişmeye sahne olmamıştır. $\mathrm{Bu}$ Rus işgallerinin birincisi olan 1828-1829 yılında Aydıntepe'de önemli bir savunma savaşı verilmiş olsa da işgal gücüne destek kuvvetlerin katılmasıyla Osmanlı ordusu Kelkit'e çekilmek zorunda kalmış ve Bayburt'ta kalan Rus askerleri burayı yağmalamıştır. Rus saldırılarından ikincisi, Birinci Dünya Savaşı sırasında, özellikle Temmuz 1916'da, Rusların işgal güçlerinin yoğunlaşması ile başlamıştır. Aynı süreçte, 19. yüzyıl sonlarında da gözlemlendiği gibi, Ermeni hâkimiyet çatışması kaynaklı zulümler yaşanmıştır. Bayburt'un tamamen işgalden kurtarılması ise 21 Şubat 1918 tarihinde gerçekleşmiştir. $\mathrm{Bu}$ zulümler zamanında memleketinden göç etmek zorunda kalan Bayburtlular da bu tarihten sonra geri dönmeye başlamışlardır (Mollamahmutoğlu vd. 2012: 17).

Milli Mücadele dönemi tarihine bakıldığında 1919 yılında Hart nahiyesinde Şeyh Eşref ve müritleri tarafından başı çekilen bir direniş hareketi izlenebilir. Bu direniş hareketi, kimi araştırmacılara göre sadece bir olay olarak anılırken kimi araştırmacılara göre de milli mücadele isyanı olarak ifade edilmektedir. Bir ay süren bu olay ya da isyan, isyancıların öldürülmesi ve müritlerin tutuklanması ile sonlanmıştır (Ural 2009: 59-60; Eliaçık 2015: 138). Milli mücadele dönemi içerisinde yörenin adının geçtiği başka bir olaya rastlanmamıştır.

19. yüzyılda yaşanan göçler ve Ermeni olayları Bayburt tarihinde önemli bir yer teşkil eder. İlk defa Ayastefanos ve Berlin Antlaşmaları ile alevlenen ve Batı güdümünde bağımsız bir Ermeni devleti kurulması fikri bu yüzyılın ikinci yarısında gelişen en önemli siyasal gelişmelerden biridir. Batı devletlerini arkasına alan Ermeniler çoğu vilayetlerde taşkınlık yapmışlar, birçok olayın vuku bulmasına sebep olmuşlardır. Bayburt'ta Ermeni olayları 1895 yılında baş göstermiş, bölge sakinleri arasında şiddetli 
çatışmalar yaşanmıştır. Şehir merkezinde başlayan çatışmalar kısa zamanda civar köylere de yayılmıştır (Özger 2008: 49-50).

Bölgede 1835 yılında yapılan ilk nüfus sayımına göre merkezde 16 mahalle ve 124 köy bulunmaktadır. Burada yaşayan Müslüman ve gayrimüslim erkek nüfusunun sayıs1 8.700 olup bu sayının \%60’ını Müslümanlar oluşturmaktadır. Kadınlar da oransal olarak dâhil edildiğinde nüfus 17.400 olarak tahmin edilebilir. Nüfusun \%84'ünün köylerde yaşadığı anlaşılmaktadır. 1835 yılında şehirde yaşayan erkek sayısı 1.394 olup \%79’u Müslümandı. 16 mahallenin 3 tanesinde sadece gayrimüslim, 12 tanesinde sadece Müslüman ve sadece Şingah Mahallesi’nde karma bir yaşam söz konusuydu. Köylerin durumuna bakıldığında doksanüç köyde tamamen Müslüman, dört köyde gayrimüslim ve yirmiyedi köyde birlikte yaşam söz konusuydu. Toplam erkek nüfus ise 7.306 kişidir (Bayburt Nüfus Defterleri 2015: 32-33).

Daha sonra yapılan nüfus sayımı kaza kaymakamı Mehmed Hüsnü Bey tarafından 1898 yılında yapılmıştır. Bu sayıma göre toplam nüfus 57.295 olup \%81'ini Müslümanlar oluşturmaktaydı. Müslüman nüfusun ise \%54'ü erkeklerden oluşurken gayrimüslim nüfusun \%52'si erkektir. Kaymakam tarafından tutulmuş istatistikler yapılan evlilikler, doğan çocuk sayısı ve cinsiyetlerini de içerisine alan geniş bir kapsam sunmaktadır (Özger 2008: 169-170). Nüfus artışında en büyük etken Gümüşhane'den Bayburt'a geçmiş olan köylerdeki nüfusun yoğun olmasıydı. Diğer taraftan göç etmiş nüfusun geri gelen kısmı da bu sayının artmasında etkilidir. Bahsi geçen işgaller ve saldırılar neticesinde şehir gelişimi zayıflamış, nüfusu azalmışsa da Cumhuriyet döneminde yeniden gelişmeye başlayacaktır.

\subsection{Aydintepe (Hart)}

Aydıntepe tarihini, yukarıda kısaca bahsedilen Bayburt tarihinden ayr1 düşünmek olası değildir. Aydıntepe ilçesinin yerleşim tarihi de en az Bayburt kadar eskidir. Yerleşime ait buluntular Eski Tunç Çağı'ndan itibaren görülmektedir (Çiğdem 2013: 71). Urartular tarafindan güvenlik için kullanılan ve çevresine yerleşimin yapıldığı Aydıntepe Kalesi, 15 ve 16 numaralı fotoğraflarda da görülebileceği üzere, 
aynı zamanda bölgenin ticari yollarını da kontrol altında tutuyordu. Çok farklı medeniyetlere ev sahipliği yapan bu bölgede Haldilerden Osmanlılara kadar birçok medeniyetin varlığ görülmektedir.

Osmanlı modernleşmesi kapsamında nahiyelerin idari taksimatta yerini alması ile Hart, 1881-1898 yılları arasında Bayburt'un 14 nahiyesinden biri olarak sayılmıştır. Aynı yıllarda nahiye müdürü Osman Ağa, yardımcısı ise Agop Ağa'dır. İlçenin 1881 yılında toplam erkek nüfusu 1.038 olup nüfusun \%97'si Müslümanlardan oluşmaktaydı. Bu y1lda Hart sadece 8 köye sahipti (Özger 2008: 200). 1898 yılında nahiye sayıs1 azalmış olsa da kendisine 52 köy bağlanarak nahiye statüsünde bırakılmıştır. 1957'ye kadar Hart ismi ile Bayburt'un nahiyesi olarak kalmış, Bayburt'un 1927 yılında Gümüşhane'ye bağlanması ile Bucak merkezi olmuştur. 1957 yılında belediye teşkilatı kurularak Aydıntepe ismini almış (Eren (tarihsiz): 28), 1987 yılında ilçe olarak Gümüşhane'ye, 1989 yılında ise o yıl il olan Bayburt'a bağlanmıştır.

Cumhuriyet döneminde Hart, kalabalık bir ilçedir. 1935 yılında 1.565 kişi olan nüfus, II. Dünya Savaşı etkisi ile azalsa da kısa zamanda artmaya başlamış, 1960 yılında 2.111 kişiye çıkmıştır. Nüfus, her sayımda ciddi oranda yükselme eğilimine girmiştir. Zira 2000 y1lı nüfus sayımlarında nüfus \%31 oranında bir gelişme ile 7.010 kişiye ulaşsa da 2011 yılı sayımlarında \%91 oranında bir düşüşle 2.570 kişiye gerilemiştir (Birinci 2015: 226-227; Ekinci 2003: 46).

2001 y1lı ilçe nüfusunda kadın erkek oranına bakıldığında, kadınların sayısının erkeklerin sayısından fazla olduğu görülmektedir. Yaşlara göre nüfus piramidine bakıldığında en kalabalık grup 15-19 yaş grubu oluşturmakta olup nüfus içindeki oranı $\% 11$ 'dir. Bu oranı takip eden ikinci en kalabalık nüfus \%10,5 ile 5-9 yaş grubudur. \%9,4 oranı ile üçüncü en kalabalık grup 0-4 yaş grubudur. En az nüfus oranı ise 80-84 yaş aralığıdır. Yörede yaşayanlar ile yapılan söyleşilerde şehrin nüfusunun 2000 yılında 7.000 kişi olduğu daha sonra hızlı bir düşüş yaşandığı fakat yaz aylarında Trabzon'dan gelen göçler ile birlikte avcılık ve yayla turizmi başta olmak üzere turizm hareketleri kaynaklı ziyaretler ve diş ülkelerden tatil için memleketini tercih edenler sayesinde 
geçici de olsa nüfusun arttığı ifade edilmiştir (Görüşme yapılan yöre sakinleri: Mehmet Salih Karadeniz, Aydoğan Dursun, Saim Bilgin; Görüşme Tarihi: 02.02.2016).

\subsubsection{Tarihi yer ve yapılart}

Çoğu tarım ve hazine avcılığg sebebi ile tahrip edilmiş olsa da Aydıntepe'de bulunan tarihi değerler aşağıdaki şekilde sıralanabilir:

Yakutiye Camii ve Haziresi, Aşağı Kırzı Köyü mezarlığı ve Ekmelüddün Baberti Türbesi, Yeraltı Şehri, Yukarı Kırzı Köyü Vank Deresi mevkii yerleşim alanı kalıntıları, Erikdibi Köyü kilise kalıntıları, Çatıksu Köyü gözetleme kulesi ve örenyeri, Gümüşdamla Köyü kemer köprü ve İrşadi Baba Türbesi, İncili Höyük, Pınargözü Köyü kilise kalıntıları, Taşkesen köyü höyükleri, Kayalık Tepe, Aydıntepe Kalesi, ilçe merkezinde bulunan medrese kalıntıları ve merkez camiden oluşmaktadır. Yapılan alan çalışmasına bağlı olarak elde edilen verilerden hareketle Aydıntepe içerisinde bulunan yerleşmeler, höyükler ve buluntular detaylı bir şekilde tarihlendirilmiştir (Çiğgem 2013: $67)$.

\section{Bölgenin Kültür ve Medeniyeti}

Aydıntepe ve çevresinde Eski Tunç Çağı ile başlayan bir kültür oluşumu vardır. Yerleşim yerlerinde karşılaşılan Karaz keramikleri bölgenin homojen bir kültür alanı içerisinde olduğunu kanıtlamaktadır. Bu kültürün canlı kaldığı kuzeydeki en son nokta burası olmuştur (Çiğdem 2013: 71). Etki alanı geniş bir bölgede yayılmış olan bu kültür, Geç Kalkolitik ve İlk Tunç Çağı boyunca kesintisiz var olmuştur. Hurrilerle olan ilişkisi kabul edilmekle birlikte, göçebe kültür özelliklerini yansıtan Hurrilerin, Karaz kültürünü gittikleri tüm bölgelerde yaydıklarına dair bir inanç da söz konusudur. Tunç Çağ́1 incelemelerinde tüm Doğu Anadolu'da hâkim kültür olan Karaz kültürünü yansıtan keramiklere Aydıntepe'de de rastlanmıştır (Sükut 2007: 17-20).

Hurri kültürünün halefi olan Hayaşa kültürünü yaşatan Hayaşa Krallığında Bayburt ve Aydıntepe oldukça önemli noktalardı ve bilakis krallı̆̆ın çekirdek merkezlerinden biri olarak dile getirilmektedir (Sükut 2007: 32). 
Hayaşa kültürünün ardından bölgede 4. yüzyıla kadar Urartu kültürü ve Daiaeni kültürü hâkim olacaktır. Bu dönem içerisinde Aydıntepe’de Hart Kalesi, Mezarlık Tepe, İncili ve Çayırköprü yerleşimleri bulunmaktaydı. Urartu egemenliğinden sonra gelen Kimmer, İskit, Med, Pers, Hellen ve Roma hâkimiyetleri ile birlikte bölgede medeniyet sürekli bir gelişme göstermiştir. Örneğin, Aydıntepe Kalesi oldukça hızlı ilerleme kat eden Kimmerlere karşı Urartular tarafından bir savunma hattı olarak yapılmıştır. Kısa dönem içerisinde çeşitli yönetim şekillerini tecrübe eden bölge, Roma'nın yıkılması sonrasında uzunca bir süre Bizans hâkimiyetinde kalmıştır (Sükut 2007: 54). Roma döneminde Aydıntepe Pontus krallı̆̆ı hâkimiyetinde kalmıştır. Yukarı Kırzı ve Aydıntepe Yeraltı Şehri bu dönemin en önemli yapılarındandır.

Ekonomi hareketliliği kadar kültürel yapısı da canlı olan Aydıntepe, İlhanlılar döneminde Darülcelal unvanı ile anıldı. "Burada Mahmudiye ve Yakutiye medreseleri kurulmuş, Mevlevilik gelişme göstermiş, ayrıca ahilik teşkilatı oldukça yayılmıştı." (Miroğlu 1992: 226) Bölgede hâkimiyet kuran her medeniyet, kültür ve din anlayışlarını da bölge halkına benimsetmiş olacağından burada bir süre Şiilik ve Safevilik kavgaları da yaşanmıştır.

Osmanlı dönemine bakıldığında kültürel durum nüfus bağlamında ortaya koyulabilir. İnbaşı (2007: 99), 1642 tarihli avarız defter kayıtlarına göre Bayburt'un kültürünü yakından etkileyen nüfus durumunu vermektedir. 16. yüzyıl ortalarına doğru gayrimüslim nüfus çoğunluktayken bu durum 17. yüzyılda isyanlardan kaynaklanan göçler sebebi ile değişim göstermiş, Müslüman nüfus artmaya başlamıştır.

16. yüzyıla ait bu defterlere göre iki cami, dokuz mescit, dört medrese, beş zaviye, bir han kâh, iki muallim hane, iki hamam gözükmekte ise de çoğu, bugüne ulaşamamış kültürel yapılardır. Selçuklu dönemine ait olan ve yine bugüne ulaşamamış yapılar, eski planlarına göre yeniden inşa edilerek canlandırılmaya çalışılmıştır. Bu yapılar arasında Cami-i Kebir, Şeyh Veysel Camii, Ferecullah Mescidi, Bekir Çelebi Mescidi, Ahi Ahmed-i Zencani Mescid ve Zaviyesi, Kadızade Mescidi, Hoca Ali Mescidi, Hasaniye Mescidi, Şeyh Hayran Mescidi, Şingah Mescidi, Haydarihane 
Zaviyesi, Hoca Yakut (Yakutiye), Sultan Fakih, Seyyid Salih zaviyeleri say1labilir (Miroğlu 1992: 227).

Bölgenin kültürel çalışmaları için dikkate alınması gereken bir diğer kaynak ise salnâmelerdir. 19. yüzyıl salnâmelerinden hareketle dönemin eğitim öğretim durumuna bakıldığında yüzyılın sonuna doğru faal medrese sayısı yirmi beş olarak ortaya çıkmaktadır. Yedi medrese şehir merkezinde iken on sekiz medrese de köylerde bulunmaktayd1. $\mathrm{Bu}$ medreselerin çoğunun çok eski dönemlerden bu yana varlığını devam ettirmiş olduğunun altını çizmek gerekmektedir. Hatta bazıları Osmanlı dönemi öncesi inşa edilmiş medreseler olup Osmanlı döneminde onarılmış ve hizmet vermeye devam etmiştir. Hart merkez ve köylerinde de medreseler bulunmaktaydı. Talebe sayıları da değişiklik göstermekteydi. Fakat genel bir toplama bakıldığında tüm Bayburt'ta senede hizmet alan medrese öğrencisi sayısı en fazla 260 olmuştur (Özger 2008: 391-400). Aynı zamanda Tanzimat dönemi Osmanlı Devleti maarif sisteminde yaşanan gelişmeler 1şığında zorunlu hale getirilen ilköğretim, yüzyıl sonuna doğru sıbyan ve iptidai mekteplerinin de çoğalmasına vesile olmuştur. Bu suretle şehirde aynı yüzyıl içerisinde iki kütüphane olduğunun da altı çizilmelidir. Bugün eğitim kurumlarına bakıldığında 1 okul öncesi, 9 ilkokul, 3 ortaokul, 1 lise bulunmaktadır. Toplam öğrenci sayısı 893, öğretmen sayısı seksendir. Aydıntepe'de ilin üniversitesine ait bir yüksekokul da bulunmaktadır. Mezuniyet oranlarına bakıldığında nüfusun \%2'si yüksekokul ve üniversite mezunu iken \%79'u ilköğretim mezunudur (Hacihasanzade 2014: 137-145).

Bölgenin tarihi anlatılırken Rus işgallerine değinilmişti. Bu savaşlar sırasında kazanılan zafer, şair Bayburtlu Zihni tarafından kaleme alınmış Hart Destanı'nda anlatılmaktadır. Aydıntepe'ye ait en önemli yazılı kültürel kaynakların başında gelen bu destan bölge hakkında bize önemli bilgiler sunmaktadır. Diğer taraftan bu işgaller sırasında fiziksel yapılarda yoğun tahribat olmuş, kültürel değerlerin çalınması vakaları ile birlikte bir kültürel kayıp yaşanmıştır. Birinci Dünya Savaşı sırasında Rusların işgal güçleri artınca bölgede göçler de yoğunlaşmıştır. Bayburt halkı bu dönemde ciddi oranda göç vermiş ve dolayısıyla bölge her anlamda gerileme göstermiştir. 


\subsection{Günümüzde Var Olan Kültürel Unsurlar}

Bugün gözlemlenen ve yöre halkının da dillendirdiği şekli ile Bayburt kültürel anlamda ve sosyal yapılaşma bağlamında Erzurum kültürüne daha yakındır. Hatta Erzurum mahalle yapısı ile Erzurum evlerinin özellikleri Bayburt mahalle yapıları ile örtüşmektedir. Evlerde haremlik ve selamlık olarak ayrılan ev bölümleri yanı sıra hayvancılığın yoğun olduğu bölgede eve bitişik ahırlar bulunmaktadır.

Aydıntepe ilçe merkezinde bugün 4 mahalle bulunmaktadır. İdari ve eğitim gibi konularla ilgili tüm kurumlar Kale Mahallesi'nde konumlanmıştır. Daha çok kasaba görüntüsü verir. Büyük bir caddesi, birbirine bitişik evleri vardır. Evler az katlı olup çoğu yeni yapılmıştır. İlçede eski mimaride inşa edilmiş ev bulmak neredeyse imkânsızdır. Köy evi olarak nitelenebilecek evler ise daha çok köylerdedir ve taş ve ahşap malzeme kullanılarak yapılmışlardır. Eski tip evler ve onların ahır, samanlık ve tandır damı eklentileri artık neredeyse tarihi bir öğe olmuştur. Çalışmanın sonunda yer alan ekler bölümünde bulunan 13 ve 14 numaralı fotoğraflarda karşılaşılan tipteki evler dışında genel anlamda Aydıntepe merkezinde eski tarz evlere rastlanamamıştır. Bugünkü konutlarda üst katlar oturma alanı iken alt katlar işyeri olarak kullanılmaktadır. Bölgesel olarak merkezden uzaklaştıkça iskân oranında azalma görülür, tarım alanları ise artmaktadır.

Cirit Bayburt'un kültürü ile bağdaşmış bir spor olup Bayburt'ta bulunan kulübü ile birlikte hâlihazırda yaşatılan bir faaliyettir. Bayburt Atlı Spor Kulübü Başkanı Arif Köprücü ile 04.02.2016 tarihinde yapılan görüşmede bu geleneğin Aydıntepe'de yaşatılmadığının altı çizilmiştir.

Kaybolmaya yüz tutmuş bir gelenek imece usulü yapılan tandırlardır ve yöre halkının yaşama dair birçok şeyi birlikte imece usulüyle yapma adetleridir.

Aydıntepe'ye ait bir el sanatı özelliğine sahip Soğanlı kabartma halıları bölgenin önemli kültür kaynağı olup dokumalarda bölgenin özellikleri izlenmektedir. 


\section{2. Ziyaret Yerleri}

Merkez Camii Haziresi: Ziyaret edilebilecek yerlerden biri, çalışmanın sonunda yer alan ekler bölümünde bulunan 17, 18, 19 ve 20 numaralı fotoğraflarda görülebilen Aydıntepe Merkez Camii ve haziresidir. ${ }^{1}$ Caminin arka bahçesinde bulunan hazire alanında; Hacı Osman el-Bayburdî, Hacı İsmail Efendizade Kurban Efendi, Yakup Ağa, Hacı Hüseyin, İmam Osman Zeyneddin, Abdu'l-Celil Efendi, Terzioğlu Halil Efendi, Hacı Ahmet Cebi’ye ait mezar taşları bulunur (Akdağ 2015: 114-235). Çoğunluğu 19. yüzyıla ait olmakla birlikte 20. yüzyıl ilk çeyreğine ait mezar taşları da bulunmaktadır. Mezarlıkların, Bursa kemeri ile benzeşen ayak şahidesi tepelikleri bulunmaktadır.

Çovrang Yayla Yerleşmesi, Göller Mevkii, Çatıksu ve Yukarı Kırzı Gözetleme Kuleleri, Aydıntepe Höyük, İncili Tepe, Çorak Höyük, Örenler Bölgesi, Kilise Tepe, Vang Deresi Kült Alanı bölgenin tarihi anlatılırken değinildiği üzere Eski Tunç, Demir Çağ, Orta Çağ ve Modern dönemlerden izler taşımaktadır.

Yer Altı Şehri: Zeminden 1.80-2.50 metre aşağıda bulunan, tüf içerisinde ve tek bir ana kayaya oyulmuş tonozlu odalardan ve galerilerden oluşan mekâna sahip bir alandır. 172 metre uzunluğunda olsa da daha geniş bir alana sahip olduğu düşünülmektedir ve kazı çalışmaları tamamlanmamıştır. Hem havalandırma hem de gözetleme için kullanılan konik biçiminde delikler mevcuttur. Ayrıca yeraltı şehri içinde bir de mezar mevcut olup son yıllarda bu mezar ziyarete kapatılmıştır. Bir ev inşaatında ilk kez ortaya çıkarılan mezarda $20 \times 20 \mathrm{~cm}$ boyutlarında üzeri yazılı bir taş ile $35 \times 22 \mathrm{~cm}$ boyutlarında üzeri yılan motifli bir taş mevcuttur. Mezarın yan kısmında ise sapan demiri, pişmiş topraktan bir çömlek ile gözyaşı şişesi bulunmuştur. Erken Hristiyanlık dönemine tarihlendirilen mezar ve kitabesi Bizans, çömlek ise Roma devrine aittir (Eren (tarihsiz) 7). Yeraltı şehrinin, Hıristiyanlık dönemlerine ait kalıntılar bulunduğundan erken Hıristiyanların dini tercihlerini özgürce yaşadıkları bir yer olduğu fikri de hâkimdir.

\footnotetext{
${ }^{1}$ Ziyaret, kış aylarında yapılmış, kapılar yoğun kar yığını sebebi ile açılamamış ve fotoğraflama ancak dışarıdan yapılmıştır. Bu çalışmada değerlendirilen kaynak eserlerde hazireye ait 2013 yılında yapılmış bir fotoğraflama mevcuttur. Hazire, bu iki ziyaret tarihleri arasında bir tadilat geçirmiştir.
} 
Aydıntepe Yeraltı Şehri’nin biri giriş biri çıkış olmak üzere iki kapısı vardır ve çalışmanın sonunda yer alan ekler bölümünde bulunan 11 numaralı fotoğrafta çıkış kapısı görülebilir. Halk arasında yeraltı şehrinin Arpalı beldesi ve Bayburt Kalesi'ne kadar uzandığına inanılsa da arkeolojik çalışmalar devam etmediğinden dolayı yeraltı şehrinin gerçek büyüklüğü hakkında kesin bilgiler yoktur. ${ }^{2}$ Çalışmanın sonunda yer alan ekler bölümünde bulunan 1 numaralı fotoğrafta bu kadim şehirden bir oda örneği görülebilir. 2 numaralı fotoğraf yeraltı şehrinde kullanılan kap1 sistemini göstermektedir. Kapı yuvarlak bir taş olup içine tam oturduğu duvara gömülü bir yuvası vardır. Taş, karşı duvara ulaştığında kapı tam olarak kapanmaktadır. 3, 5, 6 ve 7 numaralı fotoğraflar şehrin duvar ve koridor yapılarına dikkat çeker. Fotoğraflardan da görülebileceği gibi bazı kısımlar orijinalinden farklı şekilde restore edilmiştir. 4 numaralı fotoğrafa görünen duvara oyulmuş alanın kapının kapalı olduğu durumlarda gelen ziyaretçinin kim olduğu hakkında bilgi edinebilmek için açılmış bir kontrol noktası olduğu düşünülmektedir. 8 numaralı fotoğraf, galeride ve tavanda bulunan bir havalandırma noktasıdır. 9 numaralı fotoğraf, yeraltı şehrinde yaşamış olanların su kaynağ1 olarak planlanmış bir su deposu olabileceği düşünülmektedir. 10 numaralı fotoğraf ise yer altı şehrinde bulunan galerilerden bir örnektir.

Aydıntepe Kalesi: Verimli Aydıntepe ovasına hâkim bir konumda bulunur ve Trabzon'a uzanan yayla yollarını kontrol altında tutabilecek bir şekilde konumlandırılmıştır. Tamamen tahrip olmuş mimari kalıntılara ve duvar yıkıntılarına sahiptir. Bu tahribat aslında kalenin özelliklerini detaylandırabilme açısından sorun yaratmaktadır. Urartu döneminde kısmen yerleşim görmüş bir kale olduğu bilinmektedir (Ünsal 2014: 91). Bugün restore edilmiş bir yapı olarak görülebilir.

\section{3. Yörenin Ăgız Özellikleri}

Türkmen/Çepnilerin çoğunlukta olduğu Bayburt halkının konuşma dili yani geleneksel ağzı hakkında yeterli akademik araştırma yapılmamıştır. Yöre ağzını inceleyen nadir çalışmaların başında gelen Bulut (2015) kendi çalışmasında da Bayburt

\footnotetext{
${ }^{2}$ Henüz Bayburt il olmadan evvel Kaymakamı Hüseyin Eren'in yazdığı Bayburt adlı eserde de yeraltı şehrinin 5 km kadar devam ettiği iddiasına değinilmiştir (Bkz. Hüseyin Eren, Bayburt (tarihsiz) 6).
} 
yöresinin dil özelliklerini kapsamlı bir şekilde ele alan müstakil bir araştırmanın yapılmadığına dikkat çekmiştir. Bu alanda kayda geçilecek bir diğer araştırma Leyla Karahan'ın çalışmasıdır. Bu çalışmaya göre Bayburt ağzı, Doğu Grubu Ağızları içinde yer almakla birlikte Kuzeydoğu Ağız Grubu ile Doğu Ağız Grubu arasında köprü görevi görmektedir. Köprü olarak tanıtılmış olmasının nedeni, Oğuz boylarının çeşitli nedenlerle yer değiştirmeleri ve etnik köken bakımından karışmış olmalarıdır (Bulut 2015: 381-382).

Bayburt ağzının yer aldığı Doğu Grubu Ağzı dört alt gruba ayrılır ve Bayburt, II. Ağız grubunda olup İspir (Hunut grubu hariç), Erzincan merkez, Çayırlı ve Tercan ile aynı grup içerisinde değerlendirilmiştir. Bayburt ağzında bizzat halktan derlemeler yapılarak (Bayburt Merkez, Aydıntepe ve Demiröz ilçesi ve köyleri) bazı özelliklere varılmıştır (Bulut 2015: 383-384):

1. Kalınlık-incelik uyumsuzluğu söz konusudur.

Aynisi > aynıs1 / olir > olur / tutmiş > tutmuş / Mosgovi'ya > Moskova'ya

2. Düz ünlülü zaman eklerinde ünlü yuvarlaklaşması vardır.

Gelürdük > gelirdik / indük > indik / indurdular > indirdiler / İsgendorun > İskenderun

3. " $\mathrm{k}>\mathrm{h}$ " değişmesi mevcuttur.

Garayaşmah > Karayaşmak / sicah > sıcak

4. " $\breve{g}>y$ " değişmesi bazen görülür. Ama bunun yanında yine kelime içinde "ğg”nin "h"ye dönüştüğü ve de tamamen düştüğü de görülür.

Soyuh $>$ soğuk / dāya $>$ dağa / dehel $>$ değil

5. Zamir kökenli 1. ve 2. tekil kişi ekleri, bildirme ekleri ve zaman eklerinin geniş ünlülü kullanılır. Aynı eklerin dar ünlülü şekillerine de rastlanır.

Geniş Ünlülü: Tökirem > döküyorum / getürüsen $>$ getirirsin / bilmirem > bilmiyorum / gatmiram $>$ katmiyorum

Dar Ünlülü: Goyilmir > koyulmuyor / ölir > ölüyor

6. Şimdiki zaman olarak "y" de kullanılmaktadır. Her iki şekilde mevcuttur.

(-ir): tökirem > döküyorum (-ir) / goyülmir > koyulmuyor (-ir) / gavuşamirug > kavuşamiyoruz

$(-y)$ : satiy $>$ satıyor $(-y) /$ yeymiş $>$ yiyormuş $(-y) /$ yapiyöz $>$ yapıyoruz

7. Geniş zaman ekinin yuvarlak ünlülü ve dar ünlülü olarak "uk" "ük" "lk" ve “ik” şekillerinde kullanıldığı görülür.

Veririk > veririz (k) / yaparuk > yaparız (-uk) / getdüg > gittik (ük)

8. Şimdiki zaman eki "r" nin düştüğü görülür.

Gelüler $>$ gelirler / geliler $>$ gelirler / getürüsen $>$ getirirsin 
Ancak yapılan saha incelemesinde bahsi geçen özelliklerin tekrar ele alınması sureti ile daha kapsamlı bir yöre ağız çalışması yapılması gereği ortaya çıkmıştır.

\section{4. Mahalle Odalart}

Mahalle odaları geleneği hâlâ eskisi gibi yaşanan belki de yörenin en değerli gördüğü geleneklerinden biridir. Yöre halkı ile yapılan söyleşilerden edinilen bilgilere göre her mahallede bir tane Mahalle Odası bulunmaktadır. Cenaze, düğün, bayramlaşma veya olağanüstü durumlar burada hep birlikte gerçekleştirilmektedir. Söz kesme sürecinde kahve içme merasiminin de düzenlendiği bu odalar aslında ev gibi tasarlanmışlardır. Bazılarında yatakhane, mutfak, banyo bulunmakla birlikte çoğunda tuvalet, geniş oturma alanları, abdesthane bulunmaktadır. Yeni yapılar genelde daha donanımlı inşa edilmektedir. Mahalle odalarında yaz ve kış dönemlerinde ayrıca kurslar tertip edilmektedir. Aslında bugün büyükşehirlerde var olan belediye kültür merkezlerine yakın bir statüsü bulunmaktadır. Mahalleli yıllık aidatlar ödemek sureti ile odaların tüm masraflarını ortaklaşa karşılamaktadır. Mahalle odaları geleneği göç edilen büyük şehirlerde de dernek statüsünde sürdürülmektedir. Mahalle odalarından farklı olan Köy Konakları da misafirhane olup, konakların yönetimi ve masrafları konağı yaptıran aile tarafından karşılanmaktadır.

\section{5. İhram}

Bayburt'un Osmanlı hâkimiyeti sırasında kültürünün bir parçası olan giyim ve kuşamı, kullandığı aletleri seyahatname, salnâme ve tereke kayıtlarından hareketle kayıt altına alınabilir. Bu anlamda giysiler ön plana çıkar ve bölgeyi diğer yörelerden ayıran bir kadın giysisi olan ihramın özelliklerine değinmek gerekir. Hammaddesi koyunyünü olan ve dokunarak hazırlanan bu giysinin geçmişi tam olarak bilinmemekle birlikte bugün daha çok geleneksel ve yaşlı kesimin tercih ettiği bir giyim kültürü olarak hâlâ yaşamaktadır. Azalmakta olan genel kullanımı karşısında bu kültürel unsurun yok olmaması adına dokumaların evlerde veya bazı giysi parçalarına ek olarak farklı bir şekilde kullanılmakta olduğu gözlemlenmiştir. 


\section{Bölgenin İktisadi Yapısı}

Bayburt ve çevresi, Tebriz-Trabzon ticaret hattında bulunduğundan dolayı yüzyıllar boyunca Venedik ile Ceneviz kervanlarının konaklama güzergâhı üzerinde konumlanmıştır. Bu lokasyon avantajı, bölge ekonomisinin gelişimine ve hareketli bir ekonomiye sahip olmasına vesile olmuştur. Trabzon-Bayburt ve Bayburt-Erzurum hatt1 tarihi açıdan önemli bir güzergâh olarak bölgeyi dış dünyaya bağlamaktadır. $\mathrm{Bu}$ yol denize ulaşım için oldukça önemli bir yere sahipken, bölgede bulunan maden yataklarına ulaşmak için de gerekliydi. Bayburt çevresinde zengin bakır, demir, krom ve linyit yatakları olduğu bilinmektedir. Ayrıca çevrenin taş ihtiyacını karşılamak üzere kurulmuş taş ocakları da mevcuttur (Ünsal 2006: 20). Bölgede olan bu madenler ile ticari rotadaki konumu bölgenin stratejik önemini arttırmış, ticari faaliyetlerini hızlandırmıştır.

16. yüzyılın ikinci yarısına kadar iktisadi canlılığını korusa da Erzurum ve Erzincan gibi şehirlerin önem kazanması Bayburt'u ikinci plana düşürdü. 16. yüzyılda şehirde canlı bir ticaret hayatı vardı ve bu sebeple pazarlanan veya transit olarak buradan geçen ticari mallardan alınan vergiler Osmanlı İmparatorluğu için önemli oranlar teşkil ediyordu. Bu dönemde kumaş dokumacılığı ve kumaş ticareti önemliydi. Evliya Çelebi şehri ziyareti sırasında, burada her Pazar günü Kadızade Mehmed Bey Camii önünde pazar kurulduğunu, beş on bin kişinin alışveriş ettiğini, 300 dükkân ve bir bedestenin bulunduğunu, kilim ve seccade ticareti olduğunu ifade etmiştir (Miroğlu 1992: 227).

1642 tarihli Avarız defterlerine bakıldığında, Bayburt’taki askeri zümre sayısının yetmiş sekiz kişi, dini görevli sayısının ise kırk sekiz kişi olduğu görülmektedir. Meslek sahiplerine bakıldığında ise bu sayı gerçekten az görülmektedir. Bir terzi, bir hallaç, üç kitapçı, iki tacir, iki eskici olmak üzere toplamda on kişi idiler. Tüm mesleki kayıtlar avarız defterlerine girmeyeceğinden dolayı bu bilgi tamamen ve net olarak dönemi yansıtmayabilir. 158 adet köy tespit edilmiş olup 94 köyde sadece Müslüman ve 14 köyde sadece gayrimüslim yaşarken geri kalan köylerde karma bir yaşam söz konusudur. Kırda yaşayan nüfus 2254 olup \%60'1nı Müslümanlar oluşturmaktaydı 
(İnbaş1 2007: 100-102). Kırsal alanda toplam askeri zümre sayıs1 334 ve dini görevli sayısı ise 64 kişidir. Dini ve sosyal yönden bir hareketlilik olsa da idari ve askeri yönden herhangi bir hareketlilik olmamıştır. Diğer paşa sancaklarına nazaran zayıf bir görünüm sergiler (İnbaşı 2007: 107). İnbaşı bu çalışmasında köy nüfusunu da avarız defterlerinden detaylıca incelemiştir.

Fakat sonraki dönemlerde kilim ve dokuma sanatı, bölgenin diğer zanaatları gibi ciddi bir düşüş yaşamıştır. Zira 1828-1829 Osmanlı-Rus harbinde Bayburt ve çevresi de Ruslar tarafından yağmalanmış ve bu da bölgenin ekonomik kaynaklarını yadsınamayacak derecede baltalamıştır (Yanbeğ 1950: 11). Bayburt'un tarihi anlatılırken bahsi geçen ilk Rus işgali sonrası Ruslar Erzurum'a doğru çekilirken 143 hane Ermeniyi de yanlarında götürmüşlerdir. Gidenlerin içerisinde kuyumcu, ihramcı, kazancı ve demirci esnafları bulunmakla birlikte fırıncı, kebapçı, semerci, tütüncü gibi zanaatkârlar da vardı ve bu durum bölgenin ekonomisini oldukça olumsuz etkilemiştir (Özger 2008: 41). 19. yüzyılda Anadolu topraklarına zorunlu olarak göçen Müslümanlar Bayburt yöresinde de iskânlandırılmışlardır. Özellikle bir grup Çeçen’in Kırım Savaşı ve 93 Harbi sonrası Bayburt'a yerleştirildiği bilinmektedir. 93 Harbi'nde kaybedilen topraklarda yaşayan yurttaşların bir kısmı da Bayburt'a göç etmek zorunda kalmışlardır. Göç hareketleri bununla kalmamış yüzyıl sonuna doğru yaşanan bölgesel kuraklık nedeniyle Bayburt bu sefer dışarıya göç vermeye başlamıştır.

1835 yılında sadece Müslümanlardan oluşan 77 erkek nüfusa sahip olup bunlardan 31'i genç, 21'i çocuk, 25'i de yaşlı olarak sınıflandırılmıştır. 1845 yılı temettüat kayıtlarına göre ise 50 haneli idi. Sadece iki kişi hizmetli iken geri kalan tüm nüfus ziraatla uğraşmaktaydı. Bölgeye ait 202 kilelik arazinin neredeyse tamamı ekili alandı. Arpa, buğday ve sarıbaş en çok ekilen ürünlerdi. Hayvancılık ve arıcılık yaygındı. 18. yüzyılda bir medresesi ve bir mektebi vardı (Özger 2008: 238-239).

Osmanlı'nın vakıf kültürü Bayburt için de geçerlidir. 19. yüzyıla bakıldığında 60 adet vakıf bulunmaktadır. Dini ve sosyal olduğu kadar ekonomik anlamda bölge halkına hizmet veren bu vakıfların 37 tanesi şehir merkezinde iken 23 tanesi de bazı köylerde bulunmaktaydı (Özger 2008: 300). Bu sayının açıkça gösterdiği burada yaşayan halka 
bir çeşit hizmet götürme ve yardımlaşmanın genele yayıldığıdır. Bu vakıflar cami, mescit, medrese ve zaviyelerle birlikte halkın yol, su, köprü gibi ihtiyaçlarını karşılayacak faaliyetleri amaç edinen vakıflardır. Gelirleri sınırlar dâhilinde bulunan köylerin vergilerinden ama aynı zamanda kazada bulunan dükkânlardan karşılanan bu kurumlar aynı bölgenin halkına hizmet etmekteydi.

Bugüne gelindiğinde hayvancılık ve tarım için uygun düzlükleri bulunan Aydıntepe'nin, ekolojik tarım için de uygun olduğu ifade edilebilir. Sanayi ve ticaret ise gelişmemiştir. Ekonomisi uzun süredir büyük oranda tarım ve hayvancılığa dayansa da çalışan kişilere bakıldığında hizmetler sektöründe çalışanların tarım sektöründe istihdam edilenlerden daha fazla olduğu görülür. Nüfusun yarısından fazlası hizmet sektöründeyken çok küçük bir kısmı da sanayi çalışanıdır. Bölgede bir süt işleme tesisi bulunmaktadır. Buna ek olarak küçük atölyeler de mevcuttur. Fakat kişi başına gelire bakıldığında Türkiye ortalamasının çok altında bir rakamla karşılaşılır. İlçede kurulu kamu kurumları ve çalışan sayısı incelendiğinde (Birinci 2015: 230) tüm kurumları ile kendi kendine yeten bir ilçe olduğu görülmektedir.

İlçede hayvancılık büyükbaş, küçükbaş, arıcılık ve kümes hayvancılığı şeklinde incelenebilir. Küçükbaş hayvan ile kümes hayvan yetiştiriciliği 2000'li yılların başında gelir kaynakları arasında ilk sırayı paylaşmaktaydı. Büyükbaş hayvancılıkta inek yetiştiriciliği birinci sıradadır. Manda ise nadiren yetiştirilir. Küçükbaşlarda ise ilçe için önemli olan koyun ve keçi besiciliğidir. Süt ve yapağı ilçe ihtiyaçlarını karşılamakla birlikte nadiren ilçe dışına satılabilmektedir. Arıcılık gezici arıcılık şeklinde yapılmaktadır. İlçe merkezinde yıllık 100 tondan fazla bal üretilmektedir (Ekinci 2003: 82-87). Kışın uzun sürmesi besiciliğin ana maddesini kuru ot ve yeme çevirdiğinden maliyeti de arttırmaktadır.

Aydıntepe, önemli bir orman örtüsüne sahip değil, fakat geniş otlakları olmasından dolayı ekonomik anlamda yayla turizmi ve avcılık için elverişli bir bölgedir. Sınırlar içerisinde olan Yayla Göleti de yayla turizmi için doğal kaynaklardan biridir. Diğer taraftan bölgede sanayinin gelişmemesi organik tarım için olumlu kazanımlar yaratmaktadır. Özellikle arıcılık alanında organik üretim projeleri olmakla birlikte, 
Aydıntepe dâhil tüm ilde çeşitli organik üretim projeleri mevcuttur. Hayvancılık için farklı projeler de söz konusudur. Örneğin, Doğu Anadolu Projesi kapsamında, damızlık sığır işletmesi yatırımları desteklenmek suretiyle 1.828 milyon TL hibe olarak verilmiştir. Aydıntepe'de sayıca merkez ve diğer ilçeden daha az olsa da tüm tarım aletlerinin işler olduğu söylenebilir. Büyükbaş hayvan sayısı diğer ilçelerden azken küçükbaş hayvan sayısında merkez ilçeden sonra Aydıntepe ikinci sıradadır (Mollamahmutoğlu vd. 2012: 38-48).

Bayburt ili sahip olduğu çok sayıda yayla nazarında Türkiye'nin nadir illerinden birisidir. Dolayısıyla yayla turizmi bölge ekonomisinde gelişim potansiyeli olan alanlardan biridir. Aydıntepe yaylası her türlü rekreasyon faaliyetlerinin uygulanabileceği özellikte olduğundan ilin en önemli yaylalarındandır.

Aydıntepe'de bir postane ve sağlık ocağı bulunmakla birlikte Ziraat Bankası'nın da bir şubesi vardır. Yerel pazarı da bölgenin ihtiyaçlarını karşıladığından ilçe için önemli bir ekonomik faaliyettir. İlçede perakende ticaret yapan ve hizmet sunan işyerleri vardır. Ticari faaliyetlerde bulunan işyerleri ilçenin ihtiyaçlarını karşılayabilecek yapıda küçük işletmelerdir. Diğer taraftan Bayburt'a yakın olması diğer ihtiyaçların da ilden karşılanmasını olası kılmaktadır. Cuma günleri kurulan ve bölgesel ihtiyaçları karşılayan pazar haftalık bir hareketlenme sağlamakta ve yerel lokanta ve dükkânların kazançlarını da arttırmaktadır.

Bugün ilçeye bağlı 23 köyde $\mathrm{AB}$ ve KÖYDES fonları ile çalışmalar devam etmektedir. Köylerde tarım, hayvancılık ve arıcılık yoğunluktadır; maden suyu kaynakları vardır. Bazı köylerde alabalık çiftlikleri de bulunmaktadır. Bu ilçeye bağlı Aşağı Kırzı, Çatıksu, Erikdibi, Gümüşdamla, İncili, Pınargözü, Yukarı Kırzı Köyleri Bayburt'un en büyük köylerindendir. Çoğu köyde taşımalı eğitim sistemi mevcut olup kanalizasyon ve yol projeleri $\mathrm{AB}$ ya da KÖYDES desteği alınarak tamamlanmıştır. Sağlık evi/ocağı olmayan köyleri vardır. Rakımları oldukça yüksek olan köyler genelde dağlık arazilerle kaplıdır ve kış aylarında ulaşımın kapalı olduğu köyleri bulunmaktadır. Bu sebeple köylerinin çok azı tarıma elverişli alanlara sahiptir. Buğday, arpa, yonca ve ot bu topraklarda yetiştirilen tarım ürünlerine örnek olarak verilebilir (Özger 2008: 216- 
385). Özger (2008) Aydıntepe'nin köylerine ${ }^{3}$ ait ekonomi tarihinden bir kesiti özellikle 1835 yılının verilerini merkez alarak derlemiş, nüfus değerleri yanı sıra hayvancılık ve ziraat hakkında bilgiler sunmuştur.

19. yüzyılın Bayburt ekonomik yapısını araştıran Özger, çalışmasında 18441845 temettuat defterleri ile 1835-1839 nüfus yoklama defterlerinden ${ }^{4}$ faydalanarak bu yılların iktisadi yapısını ortaya koymuştur (Özger 2008: 415). Bu çalışmadan alınan bilgiler 1şığında bölge ekonomisi hakkında aşağıdaki bilgiler dikkat çekmektedir:

Şehrin gelir kaynakları ile kaynakların dağılımına bakıldığında şehrin ana geçim kaynağ1 çiftçilik, hayvancılık ve meslek gelirleri olduğu görülür. Genel itibariyle hane gelirleri oldukça düşük seyretmektedir. Şehirde yaşayan kişilerin meslek gruplarında ana kalem çiftçilik ve hayvancılık olmakla birlikte tüccar, esnaf, taşımacı, zanaatkâr, işçiler ve görevliler ile mesleği olmayanlar da bulunmaktadır. Zanaatçılık incelendiğinde dokumacılık, giyim eşyası üreticiliği, madeni eşya üreticiliği, ağaç sanayinde çalışanlar bulunmaktadır. Temettuat defterlerinde görünen bina ve işletme kayıtlarına bakıldığında ise fazla sayıda dükkân olduğu ve gelirin en büyük payının da dükkânlara ait olduğu görülür. Bununla birlikte bahçe sayısı ve oradan elde edilen icar ikinci sırayı teşkil etmekteydi. Ayrıca ticaret ağı üzerinde olduğundan bölgenin han gelirleri de bulunmaktaydı. Araştırmaya göre 1845 yılında şehir merkezinde toplam 108 bina ve işletme şehrin gelir kaynaklarından sayılmıştır.

Köylere gelindiğinde ise kaynakların azaldığı görülür. Zira o dönemde Bayburt'a kayıtlı 125 köy olmakla birlikte sadece belirli dönemin ve ancak 72 köy kayıtlarının incelenmesi suretiyle ilgili dönemin ekonomik ve sosyal yapısı çizilebilmektedir. Hanelerin çoğu bugün de olduğu gibi tarım ve hayvancılık ile geçimini sağlamaktadır. Tarım için gelişmiş yöntemler bulunmadığından ancak koşum

\footnotetext{
3 Akbulut (Abrans), İncili (Ardusta), Başpınar (Armutlu), Kılıçkaya (Yukarı Çençül), Sarıtaşlar (Aşağı Çençül), Suludere (Erginis), Çiğdemlik (Gütgüne), Dumlu (Hanege), Aşağı Kırzı Köyü, Pınargözü (Kilhons), Alaca (Menge), Erikdibi (Pağnık), Sorkunlu (Toronsos), Çayırköprü (Vağında), Çatıksu (Vanşen), Gümüşdanlı (Zargidi), Yukarı Kırzı Köyü.

${ }^{4} 27$ Temmuz 1835 tarihli nüfus sayımı Erzurum ve Van ile bağlı kaza ve köylerinin nüfusunun tahriri için verilen emir ve çıkarılan irade-i seniyye doğrultusunda icra edilmiştir. Nüfus sayımı çocuk dâhil sadece erkek nüfusu kapsamaktadır.
} 
hayvanlarıyla iş görülmekteydi. Bu da verimin oldukça düşük bir oranda kalmasına sebep olmuştur. Köylerde yaşayan hane reislerinin diğer meslekleri arasında işçi, görevli, zanaatkâr ve mesleği olmayanlar sayılabilir. İşçilerden kasıt hizmetkârlar, çobanlar, marabalardır. Zanaat sahipleri ise deri, dokuma, ağaç işçiliği ve demircilik alanında bulunmaktadırlar.

Çiftçilerin yetiştirdiği ürünler bugünkü ile pek ayrı değildir. Arpa, buğday, sarıbaş (çavdar), yonca, fĭg ile birlikte baklagiller, çeşitli meyve ve sebze de yetiştirilirdi. Köyler içerisinde hane reislerinin en fazla toprak sahipliği ikinci sıra ile Hart'ta geçerlidir. Bayburt yöresinde yaşayan hemen hemen her hanenin büyükbaş ve küçükbaş hayvanları vardı. Hem hayvanların gücünden hem de ürünlerinden faydalanılmaktaydı. Hem şehirde hem köylerde bazı haneler arıcılıkla da uğraşmaktaydılar.

1881 ve 1887 Erzurum salnâmeleri de tarım ve hayvancılık faaliyetlerini veriler 1şığında sağlamaktadır. Bu bilgilere bakıldığında her çeşit tarımsal faaliyetin yapıldığını çoğu meyvenin sınırlar içerisinde bölgeye yetecek kadar üretildiğini görmekteyiz. Nüfus istatistiklerinde de görüldüğü gibi 1898 yılında Bayburt Kaymakamı olan Mehmed Hüsnü Bey, tarım ve hayvancılığa ait istatiksel bir rapor hazırlamıştı. Bu rapor yüzyılın son günlerinde Bayburt'un genel anlamda dayanağı ve esas faaliyeti olan ziraat ve hayvancılık hakkında istatistikler sunmakta ve geliştirilmesi hususunda kıymetli bilgiler içermektedir.

Bölge, büyük oranda tarım ve hayvancılık ile ekonomik getiri elde etse de bu alanlarda da tamamen sorunsuz değildir. Daha önce de ifade edildiği gibi bu sorunların başında göç gelmektedir. Eğitim seviyesinin düşüklügü, sermaye yetersizliğgi, hayvansal ve bitkisel üretim sorunları, miras yoluyla bölünen araziler, tarımsal bilgilendirme sorunları, kooperatifçilik ve örgütlenme sorunları, pazarlama sorunları, tarım politikalarının doğurduğu sorunlar, su kaynaklarının verimli kullanılmaması bölgenin diğer iktisadi sorunlarındandır (Mollamahmutoğlu vd. 2012: 54-57). 
Bayburt sanayi verilerine bakıldığında Bayburt, Türkiye'nin sanayide az gelişmiş illeri arasında sıralanmaktadır. Genelde düşük kapasitede ve küçük ölçekli işletmelerin faaliyet gösterdiği şehrin sanayi sitesi net bir şekilde faal değildir. İlin Türkiye GSYH'sindeki payı düşük olup sosyoekonomik gelişmişlik endeksine göre 81 il içerisinde 66. sıradadır (Mollamahmutoğlu vd. 2012: 60-61). Oysa Aydıntepe ilçe merkezinde 2000'li yılların başında çalışan nüfusun \%75'i tarımsal faaliyetlerde bulunmaktaydı (Ekinci 2003: 63). Bu oranlar değerlendirildiğinde tarımsal faaliyetlerin de azalmaya yüz tuttuğu ifade edebilir. Burada etken olarak 1990 yıllarında bölgenin sulamaya açılıp mekanizasyon çalışmalarının artması görülebilir. 15 ve 16 numaralı fotoğraflardan görülebilen Hart ovası bu dönemlerde sulamaya açılmıştır. Sanayi ve nüfus ile ilgili detaylı ve en güncel göstergelere TÜİK resmi web sayfasından ulaşılabilir olmakla birlikte istatistik raporları 2013 yılına aittir. ${ }^{5}$

Durgun ticari hareketin olduğu bölgede, yöre halkı tarafından nüfusun mevsimsel ektisi, ekonominin canlanması açısından önemli bir olgu olarak görülmektedir. Nüfus oranlarına bakıldığında çalışan nüfusu ayırt etmek oldukça zordur. Yörede kadınların çalışması hoş karşılanmadığı gibi, öğrenim sebebi ile çalışmayanlar ya da bir becerisi olmayanlar da çalışabilir nüfus içerisinde sayılmaktadır. Aydıntepe'de 1985'lere kadar nüfus artış1 söz konusudur. 1940'da 7447 olan nüfus, 1955'de 8560, 1960'da 9995, 1965'de 10342, 1970'de 12030, 1975'de 12091, 1980'de 12096, 1985'de ise 12908 idi. 1970'lerden sonra nüfus artış hızı azalan Aydıntepe'de bu tarihlerden itibaren göç hız kazanmıştır. Ayrıca bu dönemler arasında Bayburt merkez bucağı ile Demirözü'nde köy büyüme oranları gerilerken sadece Aydıntepe'de köy büyüklüğü sürekli artış göstermiştir (Avcı 1994: 502-513). Bunda bölgedeki tarımsal verimliliğin etkisi büyüktür.

Daha önce de ifade edildiği gibi, Aydıntepe ilçe merkezinin tamamına yakın kısmı tarıma elverişli alanlardan oluşmakta, bu alanların büyük bir bölümünde sulama yapılmakta, tarla bitkileri ile meyve üretimi yerel ihtiyaçlar çerçevesinde devam

5 http://www.tuik.gov.tr/UstMenu.do?metod=istgosterge sayfası üzerinden erişilebilir olan: http://www.tuik.gov.tr/ilGostergeleri/iller/BAYBURT.pdf dosya istatistik verilerini sunmaktadır. Erişim Tarihi: 12.02.2017. 
etmektedir. Tarım faaliyetlerini etkileyen en önemli özelliklerin başında gelen iklimsel zorluklar Bayburt’ta tarım faaliyetlerini sınırlandırmaktadır. Kış aylarının aşırı soğuk dönemlerinde iklimsel koşullar sebebi ile tarımsal faaliyetler azalmaktadır. İlçe merkezindeki işyeri ve dükkânlar ise sadece yerel ihtiyaca cevap verecek tarzda küçük işletmelerdir. Hayvansal gıdaları genelde kendileri imal eden halk diğer gıdaları dışarıdan temin etmektedir.

\section{SONUÇ}

Aydıntepe, Geç Kalkolitik ve İlk Tunç Çağı ile tarihlenen bir geçmişe kadar uzanmaktadır. Karaz Kültürü ile başlayan kültürel boyutu Hayaşa, Daianei, Urartular, Kimmer ve İskitler ile devam etmiş; Medler, Persler ve Hellen'den sonra uzun süre Roma/ Bizans egemenliğinde kalmıştır. Selçukluların Anadolu'ya girmesiyle Türkler için ilk yerleşim yerlerinden olan Bayburt, 16. yüzyılın başlarında Osmanlı toprağ olmuştur. Türkiye Cumhuriyeti kurulana kadar Rus işgalleri dişında Osmanlı egemenliğinde ciddi bir tehditle karşılaşmamış olan bölge aslında ilk yerleşimden itibaren yoğun iskânlaşmanın olduğu bölgelerden biri olarak nitelendirilebilir.

$\mathrm{Bu}$ çalışmanın esas araştırma konusu olan Aydıntepe ilçesinin içerisinde bulunduğu Çoruh Havzası, Antik kaynaklarda belirtildiği şekli ile de vadileri yoğun olan bir alandır. Çoruh Nehri'nin de içerisinden geçtiği bu alan, eski medeniyetlerin yoğunlaştığı en önemli bölgelerden olup Pontus olarak bilinen bölgenin bir bölümüdür. Tarihsel devinim içerisinde Bayburt, tarihi ve kültürel açıdan olduğu kadar ekonomik açıdan da zengin bir şehirdi. Özellikle ticaret yollarının geçtiği ana hat üzerinde kurulu olması ve zengin madenlerinin varlığı bu bölgeyi değerli kılmıştır. Birçok medeniyete ev sahipliği yapan bölgenin tarihi içerisinde Hayaşa, Hitit, İskit, Roma, Bizans, Selçuklular, Akkoyunlular, Karakoyunlular, Osmanlı kültürleri barınma hakkını elde etmiştir. Bayburt, Türkiye Cumhuriyeti Devleti'nin kurulması ile birlikte farklı illere bağlı bucak olmasına karşın 1989 yılında il olarak kabul edilmiş ve Aydıntepe de ilçe olarak Bayburt'a bağlanmıştır. 
Bugün Bayburt kenti ile Aydıntepe, bahsi geçen birçok medeniyete ait tecrübelerin hâlâ yaşadığı ama diğer taraftan özellikle Selçuklu, İlhanlı, Akkoyunlu ve Osmanlı eserlerinin bulunduğu çok eski bir geçmişe sahip bir kent olarak varlığını sürdürmektedir. Ekonomik yapısında hizmet sektörü başta olmak üzere tarım ve hayvancılık faaliyetleri yegâne iktisadi faaliyetlerdir. Genel anlamda çok fazla göç veren bir il ve ilçe olduğunun altı çizilmelidir. Yaz aylarında artan nüfus, bölgede turistik faaliyetlere katılımı ve dolayısıyla turizm gelirlerini de artmasını sağlamaktadır. Kış aylarında oldukça sönük bir ticari hayat yaşayan bölge, sınırları içerisinde bugün 177 köyü ile tarım ve hayvancılık faaliyetleri üzerine kurulu bir bölge olarak dikkat çekmektedir. 


\section{EKLER}

\section{Aydıntepe Yeraltı Sehri'ne Ait Fotoğraflar}

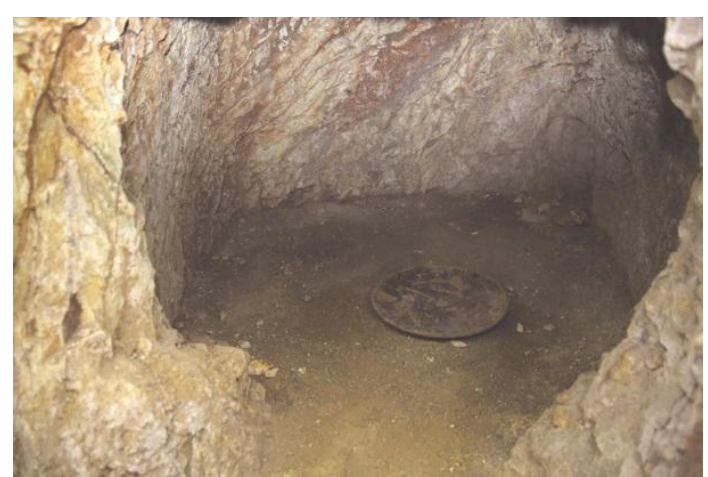

$$
\text { Fotoğraf - } 1 \text { (Oda) }
$$

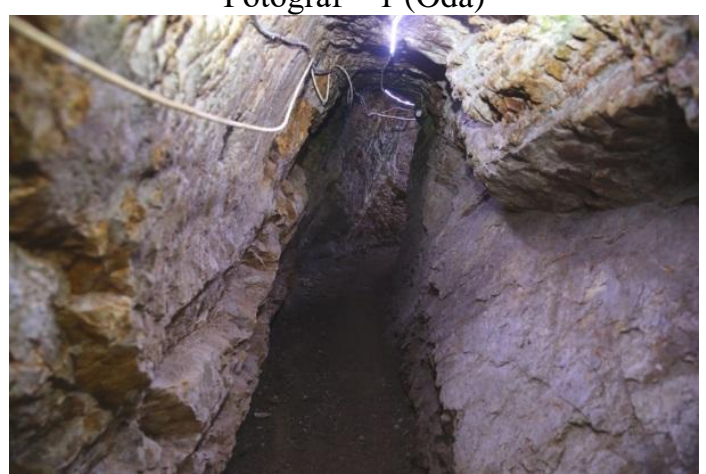

Fotoğraf -3 (Duvar ve koridor yapısı)

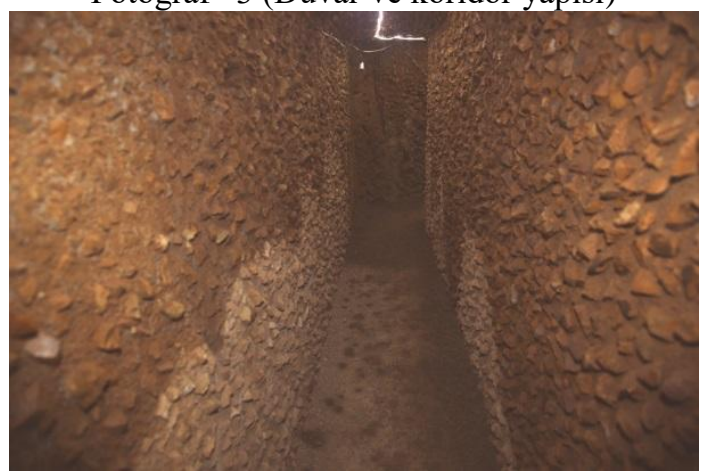

Fotoğraf - 5 (Duvar ve koridor yapıs1)

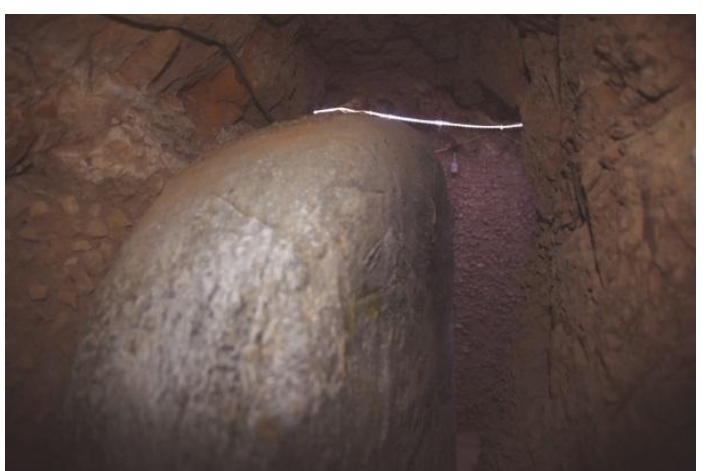

Fotoğraf - 2 (Şehrin kendi giriş kapısı)

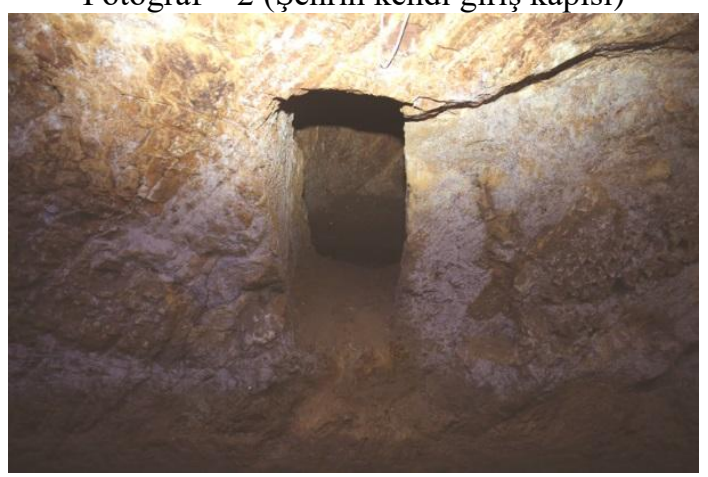

Fotoğraf - 4 (Kap1 kontrol noktası)

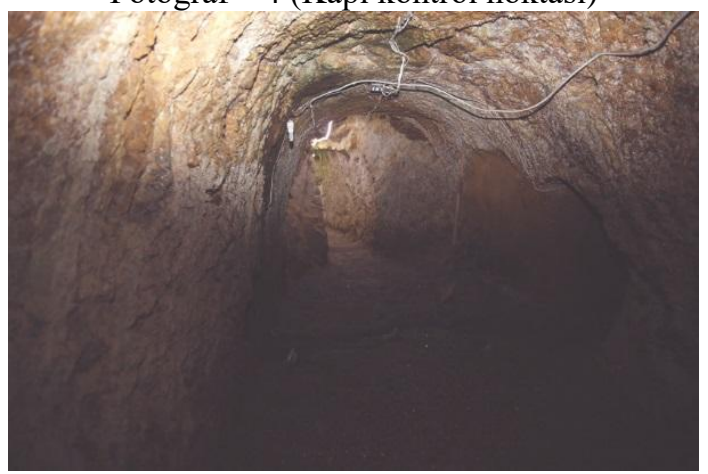

Fotoğraf - 6 (Duvar ve koridor yapıs1) 


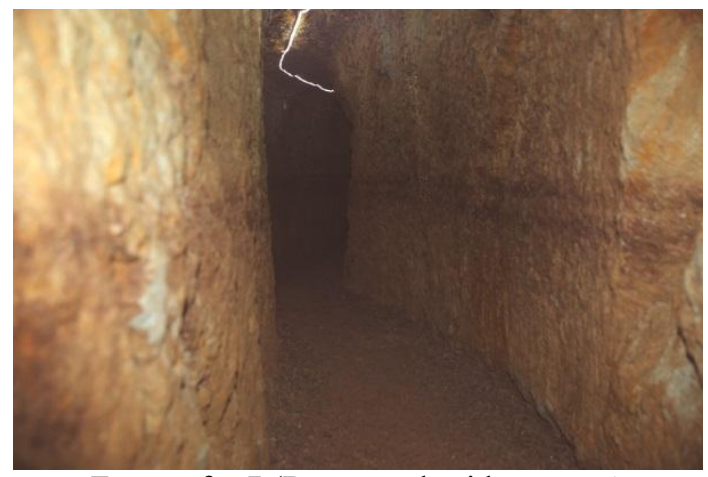

Fotoğraf - 7 (Duvar ve koridor yapısı)

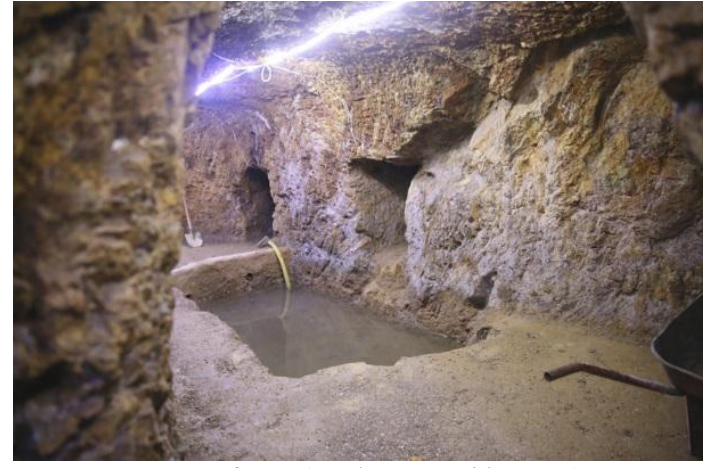

Fotoğraf - 9 (Su kaynağı/deposu))

\section{$\underline{\text { Aydıntepe Merkezine Ait Fotoğraflar }}$}

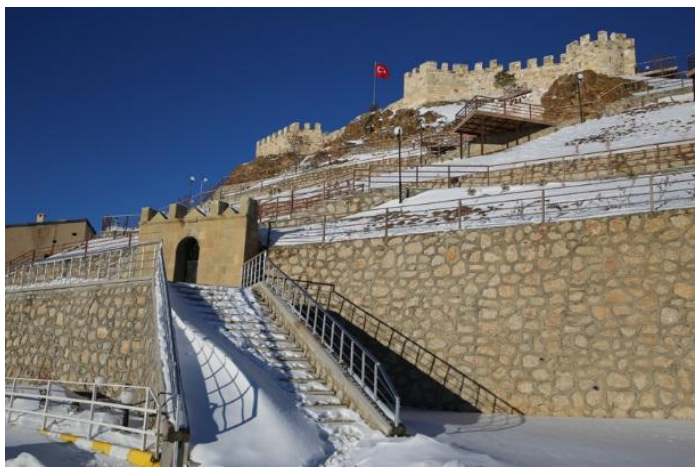

Fotoğraf - 11 (Aydıntepe Kalesi'nin altında konumlanan yeraltı şehri çıkış kapısı) ${ }^{6}$

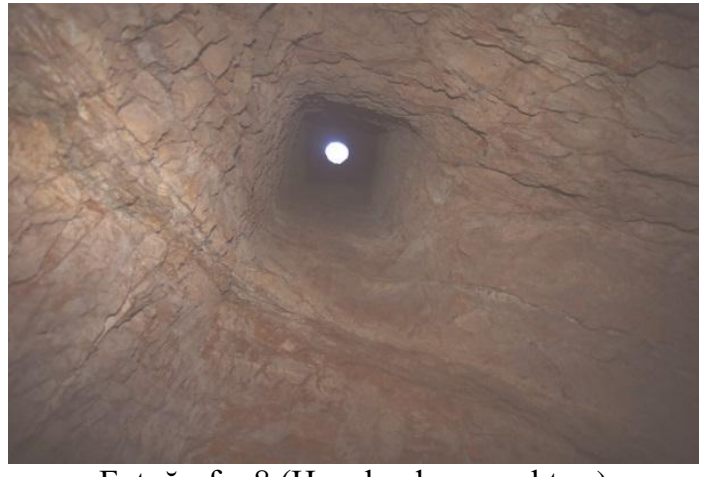

Fotoğraf - 8 (Havalandırma noktası)

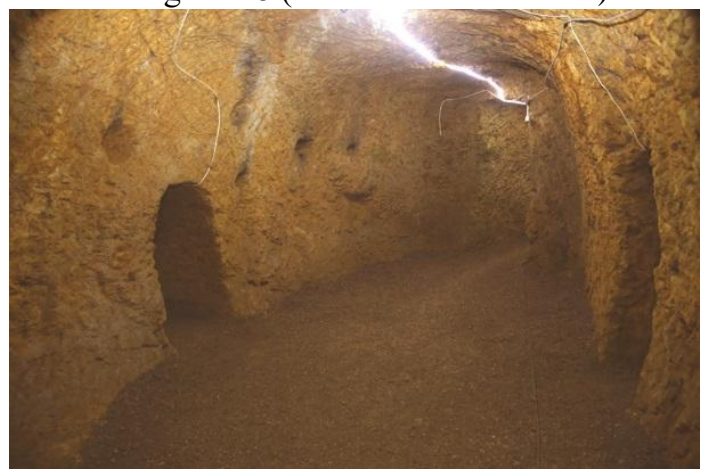

Fotoğraf - 10 (Galeri örneği)

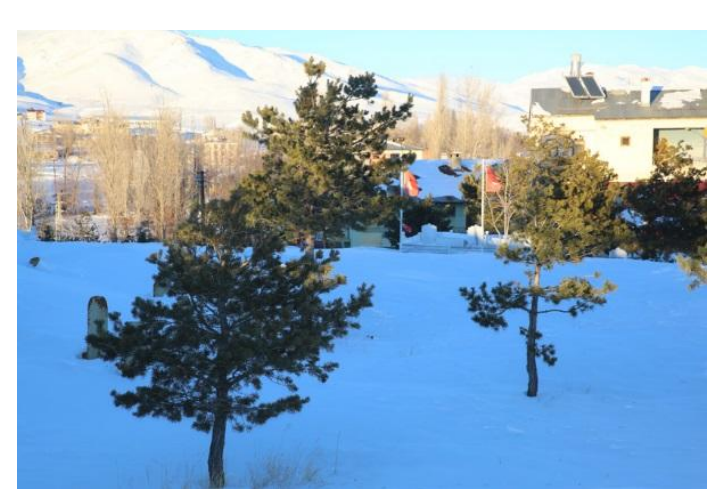

Fotoğraf - 12 (Aydıntepe Kalesi'nin üzerinden ulaşılabilen mezarlık alanı-Kayalık Tepe)

${ }^{6}$ Görevli olarak çalışan Saim Bilgin'den alınan bilgiye göre yaz aylarında ziyaretçi sayısı artmakta ve ziyaret eden yabancı turistler arasında İsrail, Hollanda, Danimarka ve Portekiz vatandaşları bulunmaktadır (Görüşme Tarihi: 02.02.2016). 


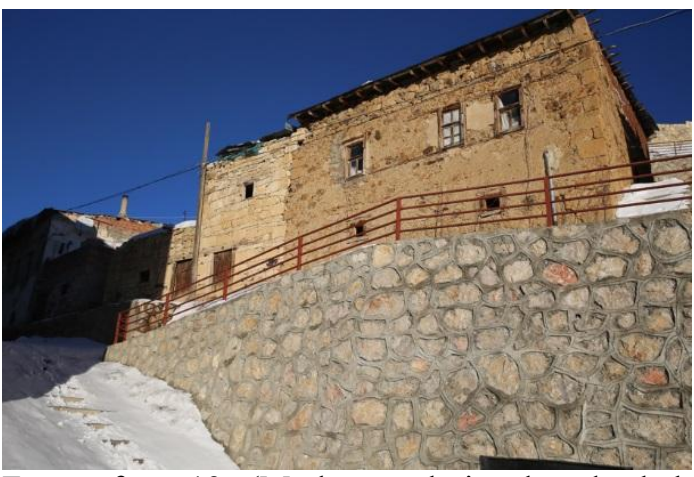

Fotoğraf - 13 (Modern evlerin dişında kalan Aydıntepe evlerinden bir görüntü)

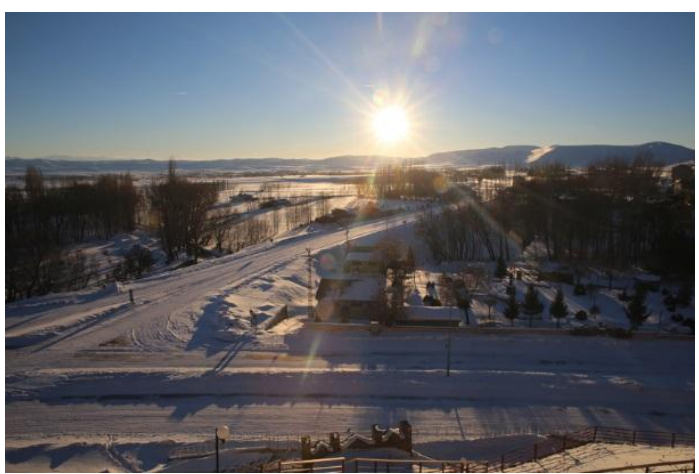

Fotoğraf - 15 (Şehrin ve Aydıntepe ovasının kaleden görünüşü)

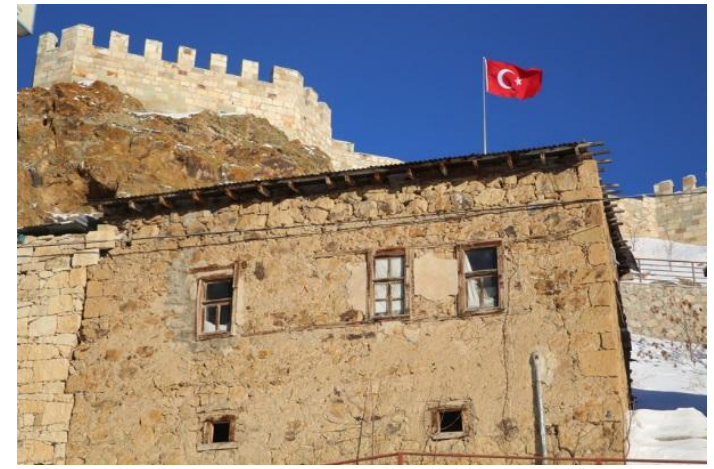

Fotoğraf - 14 (Modern evlerin dişında kalan Aydıntepe evlerinden bir görüntü)

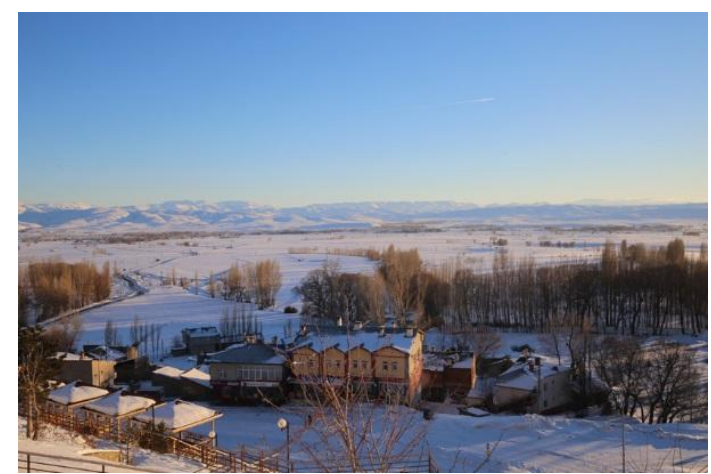

Fotoğraf - 16 (Şehrin ve Aydıntepe ovasının kaleden görünüşü)

\section{Aydıntepe Merkez Camii ve Haziresi'ne Ait Fotoğraflar}

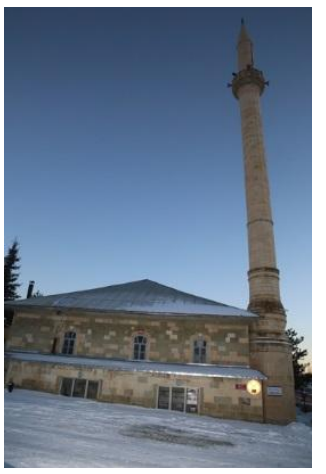

Fotoğraf - 17 (Aydıntepe Merkez Camii)

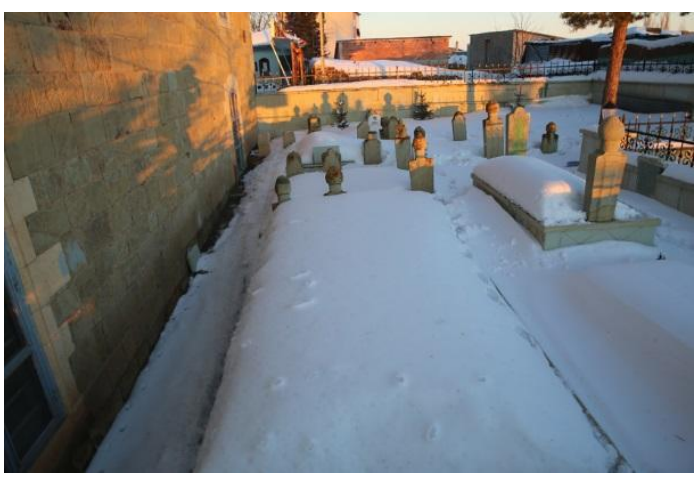

Fotoğraf - 18 (Merkez Camii Haziresi) 
Funda SONGUR, "Geçmişten Günümüze Aydıntepe",

Mavi Atlas, 5(1)/2017: 238-268.

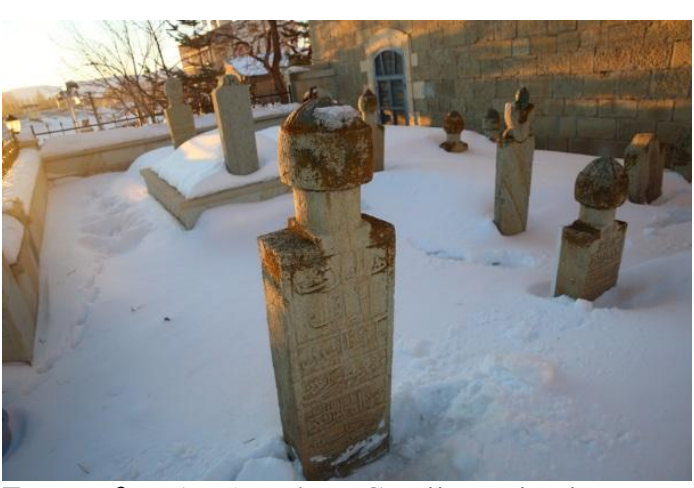

Fotoğraf - 19 (Merkez Camii Haziresi - mezar taşı: Hüve'l-hallaku'l-baki ulema-i izamdan ve müderrisin-i kiramdan Abdülcelil Efendi ruhuna Fatiha)

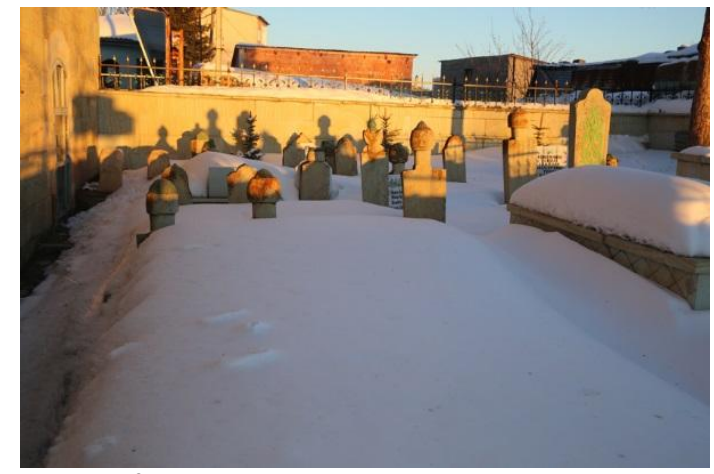

Fotoğraf - 20 (Merkez Camii Haziresi) 


\section{KAYNAKÇA}

AKDAĞ, Furgan (2015). Bayburt'taki Türbeler ve Mezar Taşları, Yayımlanmamış Yüksek Lisans Tezi, Van, Yüzüncü Yıl Üniversitesi Sosyal Bilimler Enstitüsü.

ARSLAN, Celil ve Methiye Gül ÇÖTELİ (2015). "Anadolu - Türk Şehri Tarihinde Bayburt Kenti ve Anitsal (Kamusal) Yapı Mirası", Avrasya Uluslararası Araştırmalar Dergisi, 3(6): 185-219.

AVCI, Sedat (1994). "Bayburt ve Bayburt'a Bağlı Yerleşmelerin Nüfuslarının Cumhuriyet Dönemindeki Gelişimi ve Dağılışı", 1988 Türk Tarihinde ve Kültüründe Bayburt Sempozyumu Bildirileri, haz. R. Y1ldı, ss. 495-524, Ankara.

Bayburt Nüfus Defterleri 1835-1848 (2015). haz. Yunus Özger, Bayburt Üniversitesi Yayınları Numara: 9, BAKÜTAM, Ankara: Balkan Matbaa.

BİRINCİ, Salih (2015). Bayburt İlinin Coğrafyası Fiziki-Beşeri-Ekonomik, Bayproje Yayın Numarası 16, Ankara: Detay Yayıncılık.

BULUT, Serdar (2015). "Bayburt İli Ve Yöresi Ağızlarının Türkiye Türkçesi Ağızları İçindeki Yeri”, Turkish Studies International Periodical for the Languages, Literature and History of Turkish or Turkic, 10(16): 371-386.

ÇİĞDEM, Süleyman (2013). "Bayburt/Aydıntepe Yüzey Araştırması Işı̆̆ında Bölgenin Eskiçağ Tarihinin Değerlendirilmesi”, Güzel Sanatlar Enstitüsü Dergisi, (30): 65-81.

EKİNCİ, Mehmet Emin (2003). Aydıntepe İlçe Merkezinin Coğrafyası, Yayınlanmamış Yüksek Lisans Tezi, Erzurum, Atatürk Üniversitesi Sosyal Bilimler Enstitüsü.

ELİAÇIK, Muhittin (2015). “Bayburt/Hart'ta Şeyh Eşref İsyanı'na Dair Osmanlı Arşiv Belgeleri”, Kırıkkale Üniversitesi Sosyal Bilimler Dergisi, 5(1): 119-139.

EREN, Hüseyin (tarihsiz), Bayburt, Bayburt: Bayburt Kaymakamlığı.

HACIHASANZADE, Feridun (2014). Ilçe, Belde ve Köyleriyle Bayburt, İstanbul: Has Matbaacılık.

İNBAŞI, Mehmet (2007). "Bayburt Sancağı", Atatürk Üniversitesi Sosyal Bilimler Enstitüsü Dergisi, 10(2): 89-117.

Kültürün Kale Kenti Bayburt, (2011). ed. Dursun Ali Emir ve Mutlu Adak, Ankara: Bekder Yayınları.

MİROĞLU, İsmet (1992). “Bayburt”, TDV İslam Ansiklopedisi, (5): 225-228.

MOLLAMAHMUTOĞLU, Murat; KÖSEOĞLU, Mustafa ve Şevki ÖZBİLEN (2012). Bayburt'un Sosyal, Kültürel ve Ekonomik Kalkınma Raporu, 2. Bask1, İstanbul: Has Matbaacilik. 
ÖZGER, Yunus (2008). XIX. Yüzyılda Bayburt (Sosyo-Ekonomik, İdari ve Demografik Yapı), İstanbul: IQ Kültür Sanat Yayıncılık.

PEHLIVAN, Mahmut (1994). "Başlangıçtan Urartu'nun Yıkılışına Kadar Bayburt ve Yöresi”, 1988 Türk Tarihinde ve Kültüründe Bayburt Sempozyumu Bildirileri, haz. R. Y1ldız, ss. 327-333, Ankara.

SÜKUT, Mehmet Kürşad (2007). Prehistorik Dönemden Roma'nın Sonuna Kadar Aydıntepe, Yayımlanmamış Yüksek Lisans Tezi, Erzurum, Atatürk Üniversitesi Sosyal Bilimler Enstitüsü.

URAL, Selçuk (2009). "Doğu Vilâyetlerinde Asayiş Sorunu, 1919-1920", CTAD, 5(9)41-76.

ÜNSAL, Veli (2006). Yukarı Çoruh Havzası'nın Tarihi ve Arkeolojisi: Bayburt Yöresi, Bayburt: Bayburt Valiliği Yayınları.

ÜNSAL, Veli, (2014). "Bayburt Kaleleri", Ahi Evran Üniversitesi Sosyal Bilimler Enstitüsü Dergisi, 1(1): 88-102.

YANBEĞ, Mahmut Kemal (1950). "Tarihte Bayburt'un Geçirdiği İdari Değişiklikler”, Bayburt, Numara: 1, ss. 6-13, İstanbul: Bayburt Kültür ve Yardım Cemiyeti Yayın Organı. 